\title{
Presence of the walking catfish Clarias gariepinus (Burchell) (Siluriformes, Clariidae) in Minas Gerais state hydrographic basins, Brazil
}

\author{
Carlos Bernardo Mascarenhas Alves ${ }^{1,2}$ \\ Volney Vono ${ }^{1}$ \\ Fábio Vieira ${ }^{1}$
}

\begin{abstract}
The first official occurrence of the exotic species Clarias gariepinus (Burchell, 1822) in the Rio Paraopeba (São Francisco river basin), the Rio Grande (Paraná river basin), and the Rio Doce (Doce river basin), is reported, with comments on the possible ecological consequences and on the conservation of freshwater fish biodiversity due to non-native species introductions.

KEY WORDS. Clarias gariepinus, exotic species, fish conservation, Minas Gerais, Brazil
\end{abstract}

The practice of introducing exotic fish species has been recorded since the middle ages (BALON 1974 apud Li \& MOYLE 1993). This procedure was adopted for many reasons: to increase sport fishing, to enhance aquaculture, to function as biological control of weeds and insects, to fill vacant niches in reservoirs and to be used as ornamental culture and in aquarium fish trade. In general, however, accidental introductions are more important then intentional ones (BALON \& BRUTON 1986). Among the foreseeable impacts of exotic species introduction are habitat alterations, introduction of novel parasites and diseases, increased competition with native species for food, predation of local species, hybridization, and overcrowding (TAYLOR et al. 1984).

The common carp (Cyprinus carpio Linnaeus, 1758) was the first fish species carried out of its natural range, by the Chinese (3,000 years ago), and Romans (2,000 years ago) (BALON 1974 apud Li \& MoYLE 1993). In Brazil, the first record of exotic fish species introduction occurred in 1898, when the common carp was imported with the intent of aquaculture use (WELCOMME 1988). South America is the only continent where the number of records of exotic fish introductions is still increasing, in contrast to the world wide trend of declining exotic species introductions (WELCOMME 1988). This author did not consider the introductions within different Brazilian river basins.

1) Departamento de Zoologia, Instituto de Ciências Biológicas, Universidade Federal de Minas Gerais. Caixa Postal 486, 31270-110 Belo Horizonte, Minas Gerais, Brasil.

2) Rua Rio de Janeiro, 2754/1402. 30160-042 Belo Horizonte, Minas Gerais, Brasil.

E-mail: curimata@dedalus.lcc.ufmg.br or curimata@net.em.com.br 
Development of aquaculture, and recently sport fishing (fish-out ponds, called "pesque-pague" in Brazil) are promoting the introduction of many fishes from other countries into Minas Gerais state. These include: tilapiine cichlids (Tilapia spp., Oreochromis spp. and Sarotherodon spp.), carps [C. carpio, Ctenopharyngodon idella (Valenciennes, 1844) and Hypophthalmichthys molitrix (Valenciennes, 1844)], black-bass [Micropterus salmoides (Lacepède, 1802)], and recently, the walking catfish [Clarias gariepinus (Burchell, 1822)]. Fish species from other Brazilian river basins have also been introduced, including peacock basses or "tucunarés" (Cichla spp.), oscar or "apaiari" [Astronotus ocellatus (Cuvier, 1829)], "corvina" or "pescada-do-Piaui" [Plagioscion squamosissimus (Haeckel, 1840)], "pacu-caranha" [Piaractus mesopotamicus [Holmberg, 1887)], "tambaqui" [Colossoma macropomum (Cuvier, 1818)], and hybrids between the last two species, so called "tambacu" and "paqui".

The present paper describes the first official record of Clarias gariepinus (Siluriformes, Clariidae) in the São Francisco, the Grande, and the Doce river basins, the three largest hydrographic basins in Minas Gerais state.

TEUGELs (1986), in a broad taxonomic review of genus Clarias Scopoli, 1777 , based on morphological characters and geographic distribution, recognized six subgenera (Dinotopteroides Fowler, 1930, Clarias, Platycephaloides Teugels, 1982, Brevicephaloides Teugels, 1982, Clarioides David \& Poll, 1937, Anguilloclarias Teugels, 1982), with the species C. gariepinus and C. anguillaris (Linnaeus, 1758) included in the subgenus Clarias (Clarias). Among other characteristics, these two species differ primarilly in the number of gill rakers on the first branchial arch: $C$. gariepinus $=24$ to 110 (length range between 27.7 and $600.0 \mathrm{~mm}$ ); $C$. anguillaris $=16$ to 50 (length range between 31.5 and $650,0 \mathrm{~mm}$ ). All three individuals collected had more than 50 gill rakers, and were identified as Clarias gariepinus.

During the floodings of the 1996/1997 rainy season, the water level of many Minas Gerais state rivers rose over 10 meters above their normal quota, submerging farms, lakes, small dams, and pisciculture tanks. Large floodings such as this, along with the indiscriminate introductions by unauthorized and uninformed persons, have contributed to the dissemination of exotic fish species in Brazil. In 1997, during studies at Rio Paraopeba, Rio Doce (Minas Gerais and Espírito Santo states boundary), and at the mouth of Rio do Carmo into the Rio Grande (Minas Gerais and São Paulo states boundary), three individuals of Clarias gariepinus were caught with gillnets. Their biometric data are presented in table I. The specimens are deposited in the Ichthyology Laboratory (Department of Zoology - ICB/UFMG).

The walking catfish has either an omnivorous food habit (WELCOMME 1988) or carnivorous one, feeding preferentially on fish (WINEMILLER \& KELSO-WINEMILLER 1996). Clarias shows parental care (TAYLOR et al. 1984) and at constant high temperatures, as seen in Brazil, can eliminate the discontinuity of the ovarian cycle (HUISMAN \& RICHTER 1987), allowing an extended reproductive cycle. This species is able to successfully establish where it is introduced (COURTENAY \& ROBINS 1973; COURTENAY \& STAUFFER 1984), often bringing drastic consequences to the native ichthyofauna. Other features of Clarias species, such as their capacity to travel via 
terrestrial routes (STAUFFER 1984) and their ability to tolerate low dissolved oxygen concentrations (WELCOMME 1988) due to their accessory air breathing system (STERBA 1967), allowing them to survive many hours out of water (STERBA 1967; WELCOMME 1988), give them further advantages over native fish species.

Table I. Geographic location and biometric data of Clarias gariepinus specimens caught in Minas Gerais state (Brazil).

\begin{tabular}{lllccc}
\hline River & Basin & County & $\begin{array}{c}\text { Standard length } \\
(\mathrm{mm})\end{array}$ & $\begin{array}{c}\text { Body weight } \\
(\mathrm{g})\end{array}$ & Gill rakers \\
\hline Paraopeba & \multirow{2}{*}{ São Francisco } & Juatuba & 285 & 259.0 & 56 \\
Carmo/Grande & Paraná & Uberaba & 436 & 796.8 & 75 \\
Doce & Doce & Aimorés & 463 & $796.0^{*}$ & 80 \\
\hline
\end{tabular}

*) Weight of eviscerated specimen.

STAUFFER (1984) states that this species is expanding its distribution. It is considered a pest everywhere it has been artificially introduced (WELCOMME 1984). In Brazil, the introduction of C. gariepinus (also called the African catfish) is considered clandestine (AGOSTINHO \& JÚLIO 1996). It may be necessary to follow the establishment of this non-native species in order to adopt control measures, or even to eradicate populations where they have been introduced. This is also recommended for any other fish introductions in Brazil.

The transfer of exotic species is one of the factors that is promoting changes in the structure of several aquatic communities in many Brazilian hydrographic basins (BUCKUP 1981; SANTOS et al. 1994; AgOSTINHO \& JÚlio 1996). Similar changes have occurred in other countries (ZARET \& PAINE 1973; KAUFMAN 1992). Fifteen exotic fish species, including the African catfish, have been recorded as occurring in Minas Gerais river basins. This number is probably an underestimate due to the scarcity of records of fish introductions in the scientific literature. For example, the occurrence of the rainbow trout (Salmo gairdneri) in the Serra da Mantiqueira headwater streams is commonly known, though there is no technical literature on the subject.

Brazilian law (article 34 of decree law 221, Fishing Code, 1967), is very clear concerning rules for the introduction of exotic species into the country. However, since there have been many introductions without proper technical advice, it is clear that these laws must be more strictly enforced. Current laws must be extended to enable control of importation and species transfers and to (accompanied by Environmental Impact Assessment - EIA) work with the implementation of aquaculture and fish-out ponds or put-and-take projects in Brazil. The "Instituto Brasileiro do Meio Ambiente e dos Recursos Naturais Renováveis" (IBAMA), the foremost Brazilian environmental institute, recently began working on making current laws more accessible to the general public. Further discussion is needed to clarify technical concepts in the laws, since the formal definition and elucidation of such concepts (and laws in general) will help to ensure that future impacts on the native fauna will be minimized. 
At present, Rio Grande do Sul is the only state that has special legislation (Administrative Rule 18, of December/1993, of FEPAM - Fundação Estadual de Proteção Ambiental - the state environmental protection foundation) prohibiting the culture of African catfish within its territorial boundaries. Minas Gerais state is also concerned about exotic species introductions and their impacts and the Decree Law 38.744 (4/9/1997) states that specific rules of the Environment Policy Council must be followed by where matters of exotic species introductions are concerned. However, isolated initiatives (enforcement of laws in one state only) will not prevent the dissemination of exotic fishes into other rivers, since many Brazilian rivers cross several states. Introductions into such rivers could lead to a serious risk of biodiversity loss by the impacts of exotic fishes on the native fauna. So, the simple publication of rules for exotic species manipulation is not enough to guarantee the conservation of native species and their habitats.

When the preliminary list of endangered fish species of Brazil was presented, ROSA \& MENEZES (1996) pointed out that the prohibition of non-native species introduction would increase the odds of conservation of endangered species. Without the support of previous environmental impact assessment, introductions must be banned, even if knowledge concerning conservation status of Brazilian fishes is not well studied. LowE-MCCONNELL (1987) states that Brazil has the world richest freshwater fish fauna. Practical attitudes and nationwide conscientiousness are essential for the preservation of this ichthyofauna biodiversity.

ACKNOWLEDGMENTS. The authors thank Companhia Energética de Minas Gerais (CEMIG) and Internacional de Engenharia S.A. (IESA) for the opportunity of collecting fishes in the Rio Paraopeba, the Rio Grande and the Rio Doce, during environmental studies. We also thank Dr. Naércio Aquino de Menezes (MZUSP), Dr. Guy G. Teugels (Musee Royal de L'Afrique Centrale), Dr. Mauro Luís Triques (UFMG) and an anonymous referee for their useful suggestions regarding the manuscript. Finally we would like to thank Matthew Yoder and Dr. Douglas Yanega for the English version improvement.

\section{REFERENCES}

Agostinho, A.A. \& H.F. Júlio Jr. 1996. Peixes de outras águas. Ciência Hoje 21 (124): 36-44.

BALON, E.K. \& M.N. BRUTON. 1986. Introduction of alien species or why scientific advice is not heeded. Env. Biol. Fish. 16 (4): 225-230.

BuckUP, P.A. 1981. A piscicultura de espécies exóticas e problemas ecológicos. Natureza em Revista 2: 20-23.

COURTENAY JR., W.R. \& C.R. RoBINS. 1973. Exotic aquatic organisms in Florida with emphasis on fishes: a review and recommendations. Trans. Amer. Fish. Soc. 102 (1): 1-12.

COURTENAY JR., W.R. \& J.R. STAUfFER JR. 1984. Distribution, biology and management of exotic fishes. Baltimore and London, John Hopkins University Press, 430p.

Huisman, E.A. \& C.J.J. RichteR. 1987. Reproduction, growth, health control and 
aquacultural potential of the African catfish, Clarias gariepinus (Burchell 1822). Aquaculture 63: 1-14.

KAUFMAN, L. 1992. Catastrophic change in species-rich freshwater ecosystems. BioScience 42 (11): 846-858.

LI, H.W. \& P.B. MoYLE. Domestication of the carp Cyprinus carpio L., p.287-307. In: C.C. KOHLER \& W.A. HUBERT (Eds) Inland fisheries management in North America. Bathesda, American Fisheries Society, 594p.

LOWE-MCCONNELL, R.H. 1987. Ecological studies in tropical fish communities. Cambridge, Cambridge University Press, 382p.

RosA, R.S. \& N.A. MEnEZES. 1996. Relação preliminar das espécies de Peixes (Pisces, Elasmobranchii, Actinopterygii) ameaçadas no Brasil. Revta bras. Zool. 13 (3): 647-667.

Santos, G.B.; P.M. Maia-Barbosa; F. Vieira \& C.M. López. 1994. Fish and zooplankton community structure in reservoirs of Southeastern Brazil: effects of the introduction of exotic predatory fish, p.115-132.In: R.M. PINTO-COELHO; A. GIANI \& E. VON SPERLING (Eds) Ecology and human impact on lakes and reservoirs in Minas Gerais with special reference to future development and management strategies. Belo Horizonte, Segrac, 193p.

STAUFFER, J.R. 1984. Colonization theory relative to introduced populations, p.8-21. In: W.R. COURTENAY JR. \& J.R. STAufFer JR. (Eds). Distribution, biology and management of exotic fishes. Baltimore, John Hopkins University Press, 430p.

Sterba, G. 1967. Freshwater fishes of the world. London, Studio Vista, 877p.

TAYLOR, J.N.; W.R. COURTENAY JR. \& J.A. MCCANN. 1984. Known impacts of exotic fishes in the continental United States, p.322-373. In: W.R. COURTENAY JR. \& J.R. STAUfFer JR. (Eds). Distribution, biology and management of exotic fishes. Baltimore, John Hopkins University Press, 430p.

Teugels, G.G. 1986. A systematic revision of the African species of the genus Clarias (Pisces, Clariidae). Ann. Mus. Roy. Afr. Centr. Sci. Zool. 247: 1-199. WeLCOMME, R.L. 1984. International transfers of inland fish species, p.22-40 In:

W.R. Courtenay JR. \& J.R. Stauffer JR. (Eds). Distribution, biology and management of exotic fishes. Baltimore, John Hopkins University Press, 430p. . 1988. International introductions of inland aquatic species. FAO Fish. Tech. Paper (294): 1-318.

Winemiller, K.O. \& L.C. Kelso-Winemiller. 1996. Comparative ecology of catfishes of the Upper Zambezi River floodplain. Jour. Fish Biol. 49 (6): 1043-1061.

ZARET, T.M. \& R.T. PAINE. 1973. Species introduction in a tropical lake. Science 182: $449-455$.

Recebido em 19.IX.1997; aceito em 01.III.1999. 